\title{
Leadership styles of senior executives in business and government organizations. A comparative study
}

\author{
G. Chitayat \\ General Management and Business Strategy Consultants, Ltd., Tel Aviv University, Israel \\ I. Venezia* \\ School of Business Administration, The Hebrew University, Jerusalem, Israel
}

Accepted 20 December 1987

\begin{abstract}
This article has two main objectives. First, to analyse to what extent organizational differences affect the basic relationship between style of leadership and power and information. Second, to investigate whether the results (concerning leadership styles) previously obtained for middle and lower level management also hold true for senior executives, and if not, how these should be modified. More specifically, the effects of power and information on the leadership styles of senior executives are examined and compared with those found for lower level managers. For comparison with other studies, the styles chosen for analysis were: directive, negotiative, consultive, participative and delegative. It is shown that the effects of power and information on leadership styles are not the same across organizations. Power is positively correlated with directiveness in business organizations, but negatively correlated with this style of leadership in non-business organizations. The frequency of usage of certain leadership styles is shown to vary across organizations, and the implications of these variations are discussed. It is also demonstrated that the effects of power and information on leadership styles of senior executives do not differ considerably from the comparable effects found on lower level management.
\end{abstract}

Hierdie artikel het twee hoof doelwitte. Eerstens om na te gaan in watter mate organisasie differensiasie die basiese verhouding tussen bestuurstyl en mag en inligting, beinvloed. Tweedens om na te vors of resultate (t.o.v. bestuurstyle) wat voorheen verkry is vir middel- en laervlak-bestuur ook vir senior uitvoerende beamptes geld en indien nie, hoe dit aangepas moet word. Meer spesifiek word die effek van mag en inligting op die bestuurstyl van senior bestuurders ondersoek en vergelyk met dié van laervlak-bestuurders. Om vergelyking met ander studies moontlik te maak is die volgende style gekies vir analise: Dirigerende, onderhandelende-, konsulterende-, deelnemende- en delegerende styl. Daar word aangetoon dat die effek van mag en inligting op bestuurstyl nie dieselfde is by alle organisasies nie. Mag toon ' $n$ positiewe korrelasie met ' $n$ dirigerende bestuurstyl in besigheidsorganisasies, maar 'n negatiewe korrelasie met hierdie styl in niebesigheidsorganisasies. Die frekwensie waarin sekere bestuurstyle aangewend word varieer tussen organisasies en die implikasies hiervan word bespreek. Daar word ook aangetoon dat die effek van mag en inligting op bestuurstyle van senior uitvoerende beamptes nie wesenlik verskil van dié van middel- en laervlak-bestuur, nie.

- To whom correspondence should be addressed

\section{Irtoduction}

The leadership role of senior executives of complex organizations is crucial in our society, yet knowledge of that role is both limited and unintegrated. What is known about the behaviour of senior executives of large organizations is mainly based on surveys and studies of middle and lower level management.

Inferences on the behaviour of senior executives from the behaviour of lower level managers may be biased, however, for three principle reasons. First, the superior/ subordinate relationships of senior executives differ from those of lower management. Chief executive officers (CEOs) report to the board of directors, i.e. to a group of people, whereas lower level managers usually report to an individual. Moreover, often CEOs are members of the board of directors and as such are directly responsible to the shareholders, unlike lower level managers. Second, the socio-economic status, educational level and age of senior executives may differ from those of lower level managers. It is expected that senior executives will be older and will come from a higher socio-conomic status than their lower level counterparts. The difference in background of the groups has potential of causing differences in their leadership behaviour. Third, the power and information the CEO possesses may differ from those possessed by lower level management, and this too may cause differences in behaviour. It is the objective of this article to analyse these aspects of the leadership behaviour of senior executives.

An important school of thought in leadership research is the Situational (Contingency) Leadership School (for a review see Fiedler, 1967; Hersey \& Blanchard, 1982; House \& Baetz, 1979). This school asked, among others, the following two questions. First, which style of leadership is more effective in different situations (e.g. Valenzi \& Dessler, 1978; Schrisheim \& House, 1976; House, 1971; Johns, 1978; and Jermier \& Berkes, 1979)? Second, to what extent do certain leadership styles appear to be functions of several factors? Power and information have been identified as two main variables that can explain leadership behaviour (e.g., Fiedler, 1967; Green, Nebeker \& Boni, 1975; Lowin, 1968; Heller, 1971; Bass \& Valenzi, 1974; and Bass, Valenzi, Farrow \& Solomon, 1975) ${ }^{1}$.

This study analyses whether the results previously 
obtained for middle and lower level management hold true also for senior executives, and if not, how they should be modified. More specifically, the effects of power and information on the leadership styles of senior executives are examined and compared with those found for lower level managers. For comparison with other studies, the styles chosen for analysis were: directive, negotiative, consultative, participative and delegative (defined by Bass \& Valenzi, 1974) ${ }^{2}$.

Situational leadership theory predicts that management styles will differ between government and business organizations. The differences in objectives (profit vs non-profit), organizational structure (organic vs mechanistic), and hierarchical structure (less formal in business organizations) are likely to cause differences in management styles (see e.g. Hersey \& Blanchard, $1982)^{3}$. This article explores the validity of such predictions by analysing the differences in style of senior executives in government and business organizations. It will also analyse to what extent organizational differences affect the basic relationship between style of leadership and power and information. The implications of such differences will be investigated and the usefulness of separating leadership studies based on different groups will be evaluated.

Previously it has been shown (e.g. Vroom, 1959; Jago \& Vroom, 1977; Blankenship \& Miles, 1968 and Helier \& Yukl, 1969), that the use of participative methods of lower level management increases with the hierarchical level. This article analyses whether or not these results also hold true for senior executives. In addition, the effects of age, academic education, and seniority in the current task on leadership style are examined.

\section{Mothod}

The study focuses on leadership styles employed by senior executives at the level of president (CEO) or executive vice-president of business organizations, high ranking officers in the Israeli army and senior government officials. The five leadership styles examined were: directive, negotiative, consultative, participative, and delegative. These styles were suggested and used by Bass \& Valenzi (1974) and by Bass, et al. (1975) and later utilized by Shapira (1976).

The questionnaire used in the survey (consisting of 36 questions) asked respondents to evaluate their behaviour in various circumstances. The index of each leadership style was assigned a numerical value between one and five, based on the average of the values designated by executives in their replies to the questions ${ }^{4}$. A similar approach was used to construct an index of the amount of power and information available to executives. 5 . It should be noted that the leadership styles measured here are based on the leaders' perceptions of their behaviour. Ratings by 'significant others' could have yielded different results.

The respondents were selected at random from the mailing list of the Jerusalem Institute of Management, an institute which conducts seminars for senior executives. Forty-nine of the respondents were presidents and chief executive officers of manufacturing companies; 34 were presidents and executive vicepresidents of financial institutions (commercial banks, insurance companies and investment companies); 33 were managing directors of firms owned by the kibbutz movement; 46 were at the senior vice-president level of manufacturing firms, with responsibility for a major function within the firm; 19 were directors-general of government ministries and heads of major governments agencies; and 43 were high-ranking officers (colonels and above) in the Israel Defence Forces, holding line or staff positions. The total sample comprised 224 executives.

The groups were selected so as to represent the main types of organizations operating in Israel. The separation between manufacturing firms and financial institutions seemed appropriate because of the possible different academic background of the managers in these groups (technical vs. financial), and because of differences in the ownership structure. (In Israel the control of most financial institutions is in the hands of a few families or public organizations, and the CEOs of these institutions are usually also major shareholders of their institutions.) Kibbutz managers (usually managing profit-oriented, medium-sized industrial firms) were separated from other manufacturing firms CEOs because they come from a social milieu with different ideology and values (emphasizing community life and equality between all kibbutz members) ${ }^{6}$. Senior government officials and high-ranking military officers are the non-business equivalents of senior executives in business organizations. The types of tasks in government and in the army are sufficiently distinguishable to warrant a separate analysis of the two groups, whereas the main similarities lie in the hierarchical nature of the organizations and the ambiguous (non-profit) objectives of the managers, and in the formal structure of the organizations.

The demographic profile and other characteristics of the respondents are presented in Table 1. The youngest group, and the lowest in duration of seniority at the current task, was, as expected, the high-ranking military officers; the oldest was presidents of financial companies. The relative youth of the army officers is a result of the Israeli Defence Forces policy of promoting potential officers to higher positions and encouraging early retirement by officers with low chances of promotion. That the financial institutions' presidents are, as a group, older than manufacturing executives is due to the low rate of mobility of executive bankers within the banking industry and other industry branches. The senior vice-presidents being the most educated group is due to the increased requirements for professional education in the various functions of management.

Among all managers, government officials were found to be second highest in the categories of age, seniority and education. Although a prevalence of academic advancement among respondents can in certain cases be explained by age, in this instance an additional factor 
Table 1 Personal characteristics of executives

\begin{tabular}{|c|c|c|c|c|c|c|c|}
\hline $\begin{array}{l}\text { Personal } \\
\text { variables }\end{array}$ & $\begin{array}{c}\text { Overall } \\
\text { sample } \\
(n=224)\end{array}$ & $\begin{array}{l}\text { Manufacturing } \\
\text { presidents } \\
(49)\end{array}$ & $\begin{array}{c}\text { Financial } \\
\text { inst. } \\
(34)\end{array}$ & $\begin{array}{c}\text { Kibbutz } \\
\text { (33) }\end{array}$ & $\begin{array}{c}\text { Second level } \\
\text { manufacturing } \\
(46)\end{array}$ & $\begin{array}{c}\text { Armed } \\
\text { forces } \\
(43)\end{array}$ & $\begin{array}{c}\text { Government } \\
\text { (19) }\end{array}$ \\
\hline \multicolumn{8}{|l|}{ Age } \\
\hline Up to 35 & 11,16 & 8,16 & 5,88 & 9,09 & 13,04 & 20,93 & 5,26 \\
\hline $36-47$ & 46,44 & 38,76 & 17,65 & 42,43 & 58,70 & 72,09 & 36,84 \\
\hline $48-53$ & 23,66 & 34,69 & 35,29 & 18,18 & 21,74 & 6,98 & 23,32 \\
\hline $54-58$ & 9,37 & 4,08 & 20,59 & 18,18 & 6,52 & $\mathbf{0}$ & 15,79 \\
\hline $59+$ & 9,37 & 12,29 & 20,59 & 12,12 & $\mathbf{0}$ & 0 & 15,79 \\
\hline \multicolumn{8}{|l|}{ Education } \\
\hline High School (12 yrs) & 12,95 & 10,20 & 17,65 & 18,18 & 0 & 25,28 & 5,26 \\
\hline College (2 yrs) & 25,55 & 20,41 & 35,29 & 48,49 & 26,09 & 6,98 & 10,53 \\
\hline BA/BSc & 32,14 & 24,29 & 25,53 & 27,27 & 26,09 & 53,49 & 42,10 \\
\hline MA/MSc & 20,99 & 34,69 & 20,59 & 6,06 & 30,43 & 4,65 & 26,32 \\
\hline Ph.D. & 9,37 & 10,21 & 2,94 & $\mathbf{0}$ & 17,39 & 9,30 & 15,79 \\
\hline \multicolumn{8}{|l|}{ Seniority at current task } \\
\hline 1 year & 44,64 & 28,57 & 20,59 & 39,40 & 58,69 & 76,74 & 31,57 \\
\hline $2-3$ yrs & 19,20 & 14,29 & 26,47 & 27,27 & 15,22 & 20,93 & 10,53 \\
\hline $4-6$ yrs & 7,59 & 6,12 & 8,82 & 9,09 & 8,70 & 2,33 & 21,05 \\
\hline $7-10 \mathrm{yrs}$ & 15,62 & 28,57 & 23,53 & 9,09 & 17,39 & $\mathbf{0}$ & 10,53 \\
\hline $11+y r s$ & 12,50 & 22,45 & 20,59 & 15,15 & $\mathbf{0}$ & 0 & 26,32 \\
\hline
\end{tabular}

Data are in percentages; all columns of each category total $100,00 \%$ (up to rounding errors)

Figures in parentheses indicate number of cases

emerged: government officials receive salary increments for furthering their education level, whether or not this education contributes to their job performance.

\section{Comparison of leadership styles}

Type of organization

Comparison of the leadership styles of the six sample groups was made as follows: First, the executives of business companies were matched against senior government officials; second, presidents of manufacturing firms were compared with senior executives of financial institutions; third, the group of presidents of manufacturing companies was compared with managing directors of kibbutz-owned firms; and finally, presidents were compared to second-level executives of manufacturing companies. The business group was compared to the non-business group to identify significant differences in leadership style. The presidents of manufacturing firms were compared to the presidents of financial institutions in order to analyse whether differences in the nature of operations of firms affect the leadership styles of their executives. Managers of kibbutz-owned firms were compared to the presidents group in order to investigate the effect of social norms of the kibbutz on the leadership styles of the CEOs. The results of these comparisons based on $t$ tests are summarized in Table 2 .

The following findings are inferred from Table 2: (a)

Table 2 Leadership styles, power and information in various organizations

\begin{tabular}{lcccc}
\hline & & \multicolumn{3}{c}{ Business organizations } \\
\cline { 3 - 5 } Leadership & Business (B) & Presidents (P) & Presidents (P) & Presidents (P) \\
style & vs & vs & vs & vs \\
& government & financial (F) & kibbutz (K) & second level (S) \\
\hline Directive & B less directive & P less directive & P more directive & P less directive \\
Negotiative & NSD & NSD & NSD & NSD \\
Consultative & NSD & NSD & NSD & NSD \\
Participative & B more participative & P more participative & P less participative & P more participative \\
Delegative & NSD & NSD & NSD & NSD \\
Power & B more powerful & NSD & P more powerful & NSD \\
Information & NSD & NSD & NSD & NSD \\
\hline
\end{tabular}

- NSD = no significant difference 
Executives of business companies tend more towards a participative style and less towards a directive style than do senior government officials and army officers. The difference was significant even when government officials alone were considered, but was most notable when military officers alone were compared with the business group. There were no substantial differences between the groups with regard to their use of other leadership styles. (b) Presidents of financial institutions were significantly more directive and negotiative than their counterparts in manufacturing companies. (c) Kibbutz executives were significantly more participative and less directive than CEOs of manufacturing companies. In summary, senior executives of different types of organizations differ in their use of the directive and participative leadership styles.

\section{Level of management}

The effect of management level on leadership styles was examined by comparing the leadership style of presidents and executives at the second level of manufacturing firms. Presidents were significantly less directive, less negotiative and more participative than the senior vice-presidents (Table 2). No significant evidence was found concerning the other leadership styles. The fact that presidents of manufacturing firms adopted more participative leadership styles than executives at the second level of such firms, reaffirms what has been discovered for middle level managers, namely, the higher the manager's level, the less he or she uses directive or negotiative styles.

In this case we offer the explanation that leadership style is a dynamic process. A person may change his style as a result of climbing the managerial ladder. The senior vice-president is more directive than his boss, but he may also be more participative relative to his subordinate executives.

\section{Demographic profile and career status}

No significant correlation was found between age and leadership styles, nor was there any significant

Table 3 Correlations between power and information in various organizations

\begin{tabular}{llc}
\hline Type of organization & Managerial level & Correlations \\
\hline Overall sample & Senior executive & $0,305^{*}$ \\
Business companies & Presidents, managing directors & 0,361 \\
& and second level & \\
Government agencies & Director generals and colonels & 0,099 \\
Manufacturing companies & Presidents & $0,290^{\circ}$ \\
Financial institutions & Presidents and EUP & $0,579^{*}$ \\
Kibbutz-owned firms & Managing directors & 0,007 \\
Manufacturing companies & Second level executives & $0,457^{\star}$ \\
Armed forces & Colonels & 0,082 \\
Government agencies & Directors general and & 0,080 \\
& senior officials & \\
\hline
\end{tabular}

- $P<0,01$
Table 4 Correlation between leadership styles, power and information among business executives and government officials

\begin{tabular}{lccccc}
\hline \multirow{2}{*}{$\begin{array}{l}\text { Leadership } \\
\text { styles }\end{array}$} & \multicolumn{2}{c}{ Business executives } & & \multicolumn{2}{c}{ Government officials } \\
\cline { 2 - 3 } \cline { 5 - 6 } & Power & Information & & Power & Information \\
\hline Direction & 0,29 & 0,19 & & $-0,25$ & 0,42 \\
Negotiation & 0,14 & 0,11 & & $-0,08$ & $-0,19$ \\
Consultation & 0,15 & 0,19 & & $-0,03$ & $-0,25$ \\
Participation & $-0,07$ & 0,05 & & $-0,12$ & $-0,11$ \\
Delegation & 0,12 & 0,17 & & 0,02 & $-0,15$ \\
\hline
\end{tabular}

correlation between education and leadership styles, or between seniority and leadership styles. The finding that education has no effect on leadership styles agreed with the authors' initial hypothesis. The finding that age and seniority do not affect leadership, however, seemed counter-intuitive.

\section{The effect of power and information on leadership style}

The correlation between power and information themselves was found to be very strong in the business group and insignificant in the non-business group (see Table 3).

In analysing the correlation between the two variables of the various groups no significant correlation was found for managing directors of kibbutz-owned companies, for high-ranking army officers and for senior government officials.

In analysing the data with regard to leadership styles, power and information, it was found that the two variables were correlated to the senior executive's leadership style (see Table 4). A significant correlation was found between directive style and the amount of power and information wielded by executives. However, while in business organizations this correlation was (as expected) positive, in government organizations it was slightly negative. A negative correlation between power and the directive style emerged for both military officers and government officials.

Information is, as expected, positively correlated with directive style. The intensity of the correlation, however, is stronger in the government than in business organizations. The extent to which styles other than directive style are correlated with power and information is insignificant.

\section{Implications}

It has been shown that there are considerable differences in the leadership styles adopted by senior executives of various age, seniority or education. It may seem intuitive that differences in the amount of power and information available to executives as well as differences in executives' personalities could explain the differences in the leadership styles. In what follows, it will be argued that in our study this is not the case. Executives in the business organizations had higher indices of both 
information and power than executives in non-business organizations. This indicates that if differences in leadership style were due to power and information, then business executives would have adopted the directive style to a greater extent than government and army officers. Since the opposite is true, another factor must be principally responsible for the difference between the leadership styles of the two groups.

It is the authors' conjecture that the difference in leadership styles is due to differences in the nature of the organizations ${ }^{7}$. The government and the armed forces as organizations impose a leadership style on the executive, either explicitly, via rules and procedures, or implicitly, via norms and organizational climate. The effect of organizational structure and norms on the leadership style of the executive can be inferred from another result, namely, that kibbutz executives tend more toward participative and delegative styles and less toward negotiative and directive styles than their colleagues in the business community. However, it should be noted that since being participative in all aspects of life is a major norm of the kibbutz society, the kibbutz executive is likely to choose, consciously or otherwise, a leadership style that is consistent with the norm. There may also be some selection bias, in that 'directive' institutions may hire only those who comply with their style.

In analysing the effect of power and information on the leadership style of executives, there is a puzzling result. Power is positively correlated with directiveness in business organizations, as expected, but, surprisingly, slightly negatively correlated with directiveness in nonbusiness organizations. The following explanation is offered: military officers and government officials act according to rigid rules and procedures. The directive style may therefore be imposed on them to some extent by the organization itself. Business organizations, on the other hand, consistent with the free enterprise philosophy, impose fewer constraints on executives and thus foster the use of the participative style. In the former case, the more powerful the manager of the nonbusiness organization, the more he or she can avoid regulations and procedures which impose a directive style - and employ a participative or delegative style that he or she personally may prefer.

It is not suggested by the above conclusions that power and information are not major factors affecting the determination of the leadership style of the executive. In fact, the opposite is true, as it has been shown that power and information are correlated with the extent to which the directive style is used. Ultimately, however, differences in organizational structure are more important in shaping the leadership style of the executive and better explain inter-organizational differences in leadership styles.

The high correlation between power and information in business organizations and the lack of such correlation in non-business organizations can be explained as follows: A part of the power of senior executives in business organizations is generated by their control of information, hence the high correlation between information and power. In non-business organizations, on the other hand, a great amount of authority comes with the task (rank) defined formally by the organization, and therefore power is uncorrelated with information. It should be noted, however, that a separation between information and power is more likely with lower levels of management. The tasks defined for such managers are much more structured and well-defined in a manner like that existing in nonbusiness organizations.

\section{Conclusions}

It has been shown that the effects of power and information on leadership styles of senior executives do not differ considerably from the comparable effects found on lower level management. The separation of our sample into business and non-business groups provided some new insights, however. It has been shown that the effects of power and information on leadership styles are not the same across organizations. Power is positively correlated with directiveness in business organizations, but negatively correlated with this style of leadership in non-business organizations. Moreover, the frequency of usage of certain leadership styles also varies across organizations. Presidents of business firms tend to use more of the participative style, whereas non-business managers more frequently use the directive style. The authors did not find significant differences in the use of other styles (negotiative, consultative and delegative) between these two groups.

The lack of significant correlation between personal and demographic variables and the leadership style of senior executives may be explained by the longevity of these executives in managing positions. Over the years these managers will adopt the superior style of leadership for the accomplishment of their tasks, regardless of their initial background. A change in style, however, will result when an executive moves from one type of organization to another, improves his or her control of information and power, or achieves a higher position in the managerial hierarchy.

\section{Acknowledgement}

The authors are grateful to Prof Z. Shapira, Prof S. Ronen and an anonymous referee for their constructive comments and suggestions, and to B.M. Bass for allowing us to use his questionnaire. This research has been partially funded by the Banking Research Center, Northwestern University.

\section{Notes}

1. Bass \& Valenzi (1974), for example, hypothesized that a manager who wields his power but lacks information is likely to be consultative; if on the other hand he has good access to information but lacks power, he will tend to be participative or negotiative. Finaily, a manager who lacks both power and information may tend to be delegative. This hypothesis has been tested by Bass, et al. (1975) and by Shapira (1976). 
2. Several researchers have recommended using more than the traditional two styles (Initiating structure - Consideration) in leadership analysis. See e.g. Lewin, Lippitt and White (1939); Bowers \& Seashore (1966); Taylor (1971); Heller \& Yukl (1969); Bass \& Valenzi (1974), Bass, et al. (1975).

3. The comparison between government and business organization may be viewed as a comparison between formal and less formal organizations.

4. For example, questions such as 'I tell subordinates what is expected of them' or 'I rule with an iron hand' were asked in order to construct a directiveness index. For a complete description of these questions see Bass \& Valenzi (1974). The validity of these indices was tested and confirmed by Bass \& Valenzi (1974). Details of the statistical techniques, methods and results used to reach our conclusions are presented in Chitayat \& Venezia (1984).

5. There are various definitions of power appearing in the literature (see e.g. Russell, 1938; Salancik \& Pfeffer, 1974, 1977: Kanter, 1977; Mintzberg, 1983; Dahl, 1975; and McCall, 1979). The usefulness of a formal definition of power has been discussed by Mintzberg (1983). He argues (p. 1) that experts in the field 'debate definitions of power endlessly, and how it differs from control, authority, etc. etc. Yet ordinary people seem to have no trouble with this concept. They know what it means to have power, and they can sense who has it'. This article, in accordance with Mintzberg's argument does not present a formal definition of power, yet a numerical index has been constructed to measure it, assuming managers do understand this concept. Five questions such as how frequently could you, hy yourself, override or veto any job-related decision your subordinate made', were asked to construct the power index (see also note 4 ).

6. There are many similarities, however, between CEOs of manufacturing firms and kibbutz managers. The kibbutz manager reports to the kibbutz council (equivalent to board of directors), and he or she is supposed to work for the benefit of the kibbutz members (equivalent to shareholders). The manager receives the same pay as all other members of the kibbutz but this common pay depends on the firm's success.

7. The present results may be compared with results obtained by Jermier \& Berkes (1979). They contend that '... if distinctive personality profiles among police exist, they are the product of organizational influence', i.e., the organization shapes the personality. This article claims that organizations shape the leadership style.

\section{References}

Bass, B.M. \& Valenzi, E.R. 1974. Contingent Aspects of Effective Management Styles, I. In: Hunt, J.G. \& Larson, L.L. (eds.). Contingency Approaches to Leadership. Carbondale: Southern Illinois University Press.

Bass, B.M., Valenzi, E.R., Farrow, D.L. \& Solomon, R.J. 1975. Management Styles associated with Organizational, Task, Personal and Interpersonal Contingencies. J. Appl. Psychol. 60, 720-729.

Dahl, R.A. 1975. The Concept of Power. Behav. Sci., 201-215.
Blankenship, L.V. \& Miles, R.E. 1968. Organizational Structure and Managerial Decision-Making. Admin. Sci. Quart. 13, 106-120.

Bowers, D.G. \& Seashore, S.E. 1966. Predicting Organizational Effectiveness with a Four-Factor Theory of Leadership. Admin. Sci. Quan. 11, 238-263.

Chitayat, G. \& Venezia, I. 1984. Determinants of Management Styles in Business and Non-Business Organizations. J. Appl. Psychol. 69, 437-447.

Fiedler, F.E. 1967. A Theory of Leadership Effectiveness. New York: McGraw Hill.

Green, S.G., Nebeker, D.M. \& Boni, M.A. 1975. Personality and Situational Effects on Leader Behavior. Acad. Manage. J. 4, 665-683.

Guttman, L.A. 1968. A General Non-Metric Technique for Finding the Smallest Coordinate Spaces for a Configuration of Points. Psychometrika 33, 469-506.

Heller, F.A. 1971. Managerial Decision-Making: A Study of Leadership Styles of Power Sharing Among Senior Managers. London: Tavistock Publications.

Heller, F.A. \& Yukl, G. 1969. Participation, Managerial Decision Making and Situational Variables. Organ. Behav. Human Perform. 4, 227-241.

Hersey, P. \& Blanchard, K. 1982. Management of Organizational Behavior, Utilizing Human Resources. 4th Edition. Englewood Cliffs, New Jersey: Prentice Hall.

House, R. 1971. A path Goal: Theory of Leader Effectiveness. Admin. Sci. Quart. 16, 321-338.

House, R.J. \& Baetz, M. 1979. Leadership: Some Empirical Generalizations and New Research Directions. In: Staw, B. (ed.), Research in Organization Behavior. Greenwich, Conn.: JAI.

Jago, A.G. \& Vroom, U.H. 1977. Hierarchical Level and Leadership Style. Organ. Behav. Human Perform. 18, 131-145.

Jermier, J. \& Berkes, L. 1979. Leaders' Behavior in a Police Command Bureaucracy: A Closer Look at the Quasi Military Model. Admin. Sci. Quart. 24, 1-23.

Johns, G. 1978. Task Moderators of the Relationships Between Leadership Style and Subordinate Responses. Acad. Manage. J. 21, 319-325.

Kanter, R.M. 1977. Men and Women of the Corporation. New York: Basic Boooks.

Kerr, S., Schrisheim, C., Murphy, D. \& Stodgill, R. 1974. Toward Contingency Theory of Leadership Based Upon Contribution and Initiating Structure. Organ. Behav. Human Perform. 12, 62-82.

Lewin, K., Lippitt, R. \& White, R. 1939. Patterns of Aggressive Behavior in Experimentally Created Social Climates. J. Soc. Psychol. 10,271-299.

Lowin, A. 1968. Participative Decision-Making: A Model, Literature, Critique and Prescription for Research. Organ. Behav. Human Perform. 3, 68-106.

McCall, M. W., Jr. 1979. Power, Authority, and Influence. In: Kerr, S. (ed.). Organ. Behav. Columbus, Ohio; Grid.

Mintzberg, H. 1983. Power in and Around Organizations. Englewood Cliffs N.J.: Prentice Hall.

Russell, B. 1983. Power: A New Social Analysis. London: George Allen \& Unwin. 
Selbat. G.R. \& Piefier. J. 1974. The Bases for Use of Power in Organizational Decision Making: The Case of a University. Admir. Sci. Quart. 453-473.

Sabacik. G.R. \& Piefier. J. 1977. Who Gets Power - and How They Hold on to It: A Strategic-Contingency Model of Power Organ. Dynamics 3-21.

Schrisheim. D. \& House, R. 1976. Leader Initiating Structure: A Reconciliation of Discrepant Research and Some Empirical Tests. Organ. Behav. Human Perform. 15, 297-321.

Shapira, Z. 1976. A Facet Analysis of Leadership Styles. J. Appl. Prychal. 61, 136-139.
Tannenbaum, R. \& Schmidt, W.H. 1973. How to Choose a Leadership Pattern. Harv. Bus. Rev. 3, 162-169.

Taylor, J.C. 1971. An Empirical Examination of a Four-Factor Theory of Leadership Using Smallest Space Analysis. Organ. Behav. Human perform. 6, 249-266.

Valenzi, E. \& Dessler, G. 1978. Relationships of Leader Behavior, Subordinate Role Ambiguity and Subordinate Job Satisfaction. Acad. Manage. J. 4, 671-678.

Vroom, U.H. 1959. Some Personality Determinants of the Effects of Participation. J. Abnorm. Soc. Psychol. 59, 322-327. 